\title{
The "Me Too" and "Time's Up" Movements in The Guardian
}

Tsvetelina Dzhambazova

Faculty of Journalism and Mass Communication, SU "St. Kliment Ohridski," Sofia, Bulgaria

\section{Движенията "Me Too" и "Time's Up" в The Guardian}

\author{
Цветелина Джамбазова
}

Факултет по журналистика и масова комуникация, СУ „Св. Климент Охридски", София, България

\section{Author Note}

\section{Tsvetelina Dzhambazova (1) https://orcid.org/0000-0002-8540-9635}

The author has no conflict of interest to disclose.

Correspondence concerning this article should be addressed to Tsvetelina Dzhambazova, Sofia 1000, 49 Moskovska str., Faculty of Journalism and Mass Communication. Email: tsvetelina_dzhambazova@abv.bg

\section{Бележки за автора}

\section{Цветелина Джамбазова 1 https://orcid.org/0000-0002-8540-9635}

Няма конфликт на интереси.

Кореспонденцията, свързана с тази статия, да бъде адресирана до Цветелина Джамбазова, София 1000, ул. „Московска" № 49, Факултет по журналистика и масова комуникация. Email: tsvetelina_dzhambazova@abv.bg 


\begin{abstract}
The article analyzes the author's content analysis results on texts about the new social justice movements "Me Too" and "Time's Up. „The analyzed materials are published on The Guardian's website (theguardian.com) between October $5^{\text {th }}, 2017$, and December $31^{\text {st }}, 2018$, (thus marking both campaigns' first anniversary). The text aims to study the methods through which both initiatives are presented in the British medium. The article's important tasks are researching whether this website's authors express an attitude towards the movements and checking out whether there is any connection between these campaigns and the existing calls for changes in the social roles of sexes in modern society. The Guardian's journalists actively present attempts to eliminate violence and simultaneously express a largely positive attitude toward those activists' actions and efforts to eradicate gender discrimination. The published materials are characterized by a significant generic variety, while calls for changes in men and women's social roles can often be found in the analyzed texts. In the end, readers are fully informed about the most important facts surrounding the two movements, which once again proves the huge The Guardian plays in supporting and promoting gender equality values.
\end{abstract}

Keywords: "Me Too," "Time's Up," The Guardian, social movements, social roles, content analysis

\title{
Резюме
}

Чрез метода контент анализ в статията се изследват интерпретативни текстове относно новите движения за социална справедливост "Ме Тоо" и "Time's Up", публикувани на уебсайта на вестник The Guardian (theguardian.com) в периода 5 октомври 2017 г. - 31 декември 2018 г., обхващащ първата година от създаването на кампаниите. Целта е да се проследят начините, по които двете инициативи са отразени от британската медиа чрез специално създаден за целта Кодбук и кодировъчни регстрационни листове. Основни задачи пред изследването са анализиране дали в онлайн изданието е изразено отношение към движенията и проследяване дали журналистите в медията виждат връзка между тях и съществуващите призиви за промяна на социалните роли на половете в съвременното общество. Публикуваните материали се отличават с голямо жанрово разнообразие, а призивите за промяна на типичните социални роли на мъжете и жените често присъстват в изследвания масив. По този начин са отразени различни аспекти на фактите около движенията, като се дава възможност на читателите да си създадат една относително пълна представа за всичко случващо се около инициативите. Авторите в The Guardian ca 
активни в отразяването на борбата за премахване на сексуалното насилие и изказват основно положително отношение към активистите на инициативите и техните стремежи за преодоляване на дискриминацията въз основа на пола.

Ключови думи: "Ме Тоо", "Time's Up", The Guardian, социални движения, социални роли, контент анализ

ARTICLE INFO:

Original Article

Received: 17, 09.2020

Revised: 01, 10.2020

Accepted: 20, 10.2020 


\section{Движенията "Me Too" и "Time's Up" в The Guardian}

Макар и съществуващо от почти 15 години движението "Ме Тоо" става популярно едва след вълната от обвинения в сексуален тормоз срещу филмовия продуцент Харви Уайнстийн, започнала през октомври 2017 г. Решаващо значение за популяризирането на инициативата има употребата в Туитьр на хаштаг \#МеТоо от актрисата Алиса Милано, който води до масовото споделяне на истории за сексуално насилие по целия свят.

Движението "Time's Up" започва на 1 януари 2018 г., когато някои от найвлиятелните актриси в Холивуд излизат с писмо, в което заявяват, че създават това движение с цел да се прекрати практиката на сексуален тормоз на работното място. Заедно с него започва да действа и специален Фонд за правна и финансова помощ, който да окаже подкрепа на жертвите на сексуално насилие на работното място (както мъже, така и жени), които биха искали да започнат правни действия срещу своите насилници, но нямат средствата да го направят. Основна задача на Фонда е да свързва жертвите с адвокати, готови да поемат техния казус.

В настоящата статия е проследено по какъв начин тези нови социални движения са отразени на уебсайта на британския вестник The Guardian, theguardian.com. Целта е да се проследят начините, по които двете движения са отразени от медията. Основни задачи пред изследването са анализиране дали в това издание е изразено отношение към движенията и проверка дали журналистите в медията виждат връзка между тях и съществуващите призиви за промяна на социалните роли на половете в съвременното общество.

Сексуалният тормоз като самостоятелен проблем за изследване (и изобщо като изследователски проблем) започва да се разглежда едва в началото на 80-те години на 20-ти век, което е ясен знак за това колко силно е бил подценяван този въпрос - от обществото, а след това и от учените. Пьрвото голямо изследване се появява през 1979 г. в книгата на Катрин МакКинън (MacKinnon, 1979). След излизането на тази книга сексуалният тормоз става значително по-видим, а и все повече изследователи предлагат варианти на широкото социокултурно обяснение на МаКинън, които стават все попопулярни (Schultz, 2001; MacKinnon, 2002; Tangri et al., 1982). Появяват се и редица критици, които прилагат доказателства за случаи на мъже мишени на сексуален тормоз (Kalof et al., 2001; Thacker, 1996), чрез които започват да предизвикват феминистките възгледи за сексуалния тормоз като действие, извършено от силни възрастни мъже 
спрямо „безсилни" жени (Patai, 1988, p. 170), и да ги считат за основани върху „неизследвани понятия за мъжка власт и хищническа природа" (Patai, 1988, p. 50).

През 70-те и 80-те години на 20-ти век жените заемат все повече и повече работни места, а от друга страна, изследователите на феминизма все по-стриктно повдигат въпроса, че жените се намират в подчинено положение спрямо мъжете - не само у дома, но и на работното място. Така не е изненадващо, че обществото започва да смята за непозволени и непоносими сексуалните заплахи и репресии, обидите, сексуалните намеци и сексуалния хумор, които до този момент са били пасивно изтърпявани от жените. Жените предизвикват мъжкото негодувание, като едновременно възприемат нови властнически роли в бизнеса и в сферата на труда и като нахлуват в сигурния до този момент мъжки бастион на физическата работа (напр. въглищните мини, строежите, полицейските участъци). Това негодувание, свързано с все по-голямото общуване между мъже и жени на работното място, без съмнение е още една предпоставка за появата на сексуалния тормоз (Frankel, 1990, p. 333).

Учените, занимаващи се с изследването на сексуалния тормоз, фокусират вниманието си основно върху два големи теоретични диспута. При първия става въпрос за разбиранията на мъжете и жените за същността на сексуалния тормоз. Оказва се, че тези разбирания се различават значително, оставяйки широко място за недоразумения, но и затруднявайки премахването на този вид сексуално насилие. Основно предизвикателство тук е, че един и същ начин на поведение може да бъде видян от мъжете като обикновен флирт, а от жените - като сигнал за опасност от сексуално насилие (Tavris et al., 1977; Crain et al., 1995). При втория теоретичен дебат се търси отговор на въпроса дали при сексуалния тормоз става дума за удовлетворяване на сексуално желание или за придобиване на по-голяма власт - тук мненията често са противоположни (Newman, 1995; Brodsky, 1976; Bargh et al., 1995).

Широката употреба на социалните медии както за лични, така и за професионални нужди, оказва влияние и върху съвременните концепции за сексуалния тормоз. Традиционните гледни точки относно тормоза изразяват разбирането, че той се случва в границите на работното място. Контактите в социалните мрежи извън тези рамки обаче създават необходимост да се преразгледат тези идеи (Blakely, 2009; Mainiero et al., 2013). Активността на хората в социалните медии днес е от съществено значение при проследяване на развитието на движенията "Me Тоо" и "Time's Up". Инициативите са в началото на своето съществуване, но започва да се натрупва научна литература, 
разглеждаща техни аспекти (Thomson, 2018; Zilles, 2017; George, 2018; Leung et al., 2019). Предстои обаче по-подробното проучване на тези движения от изследователите.

\section{Метод}

Чрез метода контент анализ са кодирани 212 персонализирани интерпретативни текста, публикувани в периода между 5 октомври 2017 г. и 31 декември 2018 г., обхващащ първата година от съществуването на инициативите. За целта предварително бе специално създаден Кодбук (Macnamara, 2005). В статията са проучени материали относно движенията "Me Toо" и "Time's Up", в които инициативите са изведени като основна тема. Включени са и текстове, в които не се споменава пряко някое от движенията, но въпреки това са свързани пряко със случващото се и с резултатите от кампаниите за премахване на сексуалното насилие.

Събраният емпиричен материал е изследван по 6 категории със съответни релевантни категориални признаци. Имат се предвид категориите:

1. Жанр;

2. Заглавие - типология;

3. Интонация и аргументация;

4. Изразено отношение към движенията "Me Toо" и "Time's Up";

5. Дали в текста се говори за "Ме Тоо" или за "Time's Up";

6. Има ли призив за промяна на социалните роли на мъжете и жените в тези текстове.

Към всяка една от категориите са изследвани и кодирани съответните признаци. Така към категорията жанрове са изследвани и кодирани тяхните оценъчни, наративни и диалогични жанрови признаци. Такива интерпретативни жанрове са: интервю, лично мнение, коментар, репортаж, есе, статия, анализ, рецензия, портрет и писма (Monova, 1999).

Заглавието бе типологизирано в равките на две самостоятелни категории:

„Заглавие според изразните средства": Според изразните средства изведохме следните признаци:

- Фактологично;

- Метафорично;

- Инсинуативно;

- Символно;

- Иронично. 
„Заглавие, според семантичната структура" Имаха се предвид следните категориални признаци или показатели:

- Номинативно;

- Наративно;

- Призивно, подбуждащо;

- Неутрално;

- Хипотетично (Monova, 2000, p. 42).

Интонацията като самостоятелно предвидена категория бе изследвана със следните категориални признаци: констатираща, утвърждаваща, отричаща, подбуждаща, призивна, остра, иронизираща, спокойна (неутрална, дистанцирана, официална) (Monova, 2012, p. 24).

Вкючената в Кодбука (регистрационната карта) категория аргументация е рамкирана по следните признаци - рационална или емоционална. Изследваше се какво е съотношението между рационалните и емоционалните елементи в текста; дали има някакъв опит за манипулация чрез начините, по които е изграден конкретният материал; дали аргументацията е предимно фактологично построена или се работи чрез чувствата.

\section{Резултати и дискусия}

Медиата проявява траен и стабилен интерес към темите, свързани с движенията "Me Toо" и "Time's Up", през всичките 15 месеца на настоящето изследване. Само по себе си това е доказателство за ангажираността на пишещите в уебсайта към широкоразпространения проблем сексуално насилие. Тема, която до този момент често е била пренебрегвана и така и не е подлагана на сериозна обществена дискусия - факт, който създава пречки пред преодоляването на проблема. Отразяването на всичко случващо се около двете инициативи е начинът, който британската медия предлага за премахване на табуто върху обсъждането на сексуалния тормоз и насилие.

Жанрова характеристики. Аргументация и интонация

Таблица 1

The Guardian - интерпретативни текстове по жанрове

\begin{tabular}{|c|c|c|}
\hline \multicolumn{3}{|c|}{ Интерпретативн текстове (общ брой текстове - 212) } \\
\hline Жанр & Бройки & \% \\
\hline Интервю & 12 & 5,66 \\
\hline Лично мнение & 74 & 34,91 \\
\hline Коментар & 26 & 12,26 \\
\hline Репортаж & 21 & 9,91 \\
\hline Есе & 13 & 6,13 \\
\hline Статия & 15 & 7,08 \\
\hline
\end{tabular}




\begin{tabular}{|c|c|c|}
\hline Жанр & Бройки & \% \\
\hline Анализ & 28 & 13,21 \\
\hline Рецензия & 6 & 2,83 \\
\hline Портрет & 16 & 7,55 \\
\hline Писма & 1 & 0,47 \\
\hline
\end{tabular}

Таблица 1 дава представа какви са конкретните интерпретативни жанрове, които са използвани в онлайн изданието на The Guardian. Прави впечатление, че жанрьт с наймного публикации е личното мнение - 74 текста/ 34,91\% от всички интерпретативни материали, което далеч надвишава броя на останалите жанрове на интерпретативния дискурс, които се срещат в тази медиа. Всъщност жанрът лично мнение е една от основните особености на уебсайта, в който е обособена специална рубрика „Мнения". Част от тази рубрика са редовните седмични колонки на журналисти. Лични мнения се публикуват и от странични наблюдатели, заинтересовани от развитието на двете движения. Голямото разнообразие от гледни точки, изразени чрез този жанр, помага на читателя да се ориентира в огромното количество информация, а и да оформи свой собствен възглед за случващото се.

На второ и трето място се нареждат анализът и коментарът - съответно с 28 текста $(13,21 \%)$ и с 26 текста (12,26\%). На предпоследно място пък е рецензията с 6 публикации (2,83\%), а на последно място са писмата с 1 текст (0,47\%). Така може да се каже, че в онлайн изданието на The Guardian ce открива разнообразие при използваните интерпретативни жанрове. Срещат се текстове от цели 10 жанра - интервю, лично мнение, коментар, репортаж, есе, статия, анализ, рецензия, портрет и писма. Чрез това жанрово разнообразие се осигурява разглеждането на различни страни от социалните факти, даващо възможност за по-добро разбиране на реалността, свързана с развитието на движенията "Мe Тоо" и "Time's Up".

Заглавията на интерпретативните текстове също се отличават с много голямо разнообразие. Често се срещат призивни и подбуждащи заглавия, а сьщо и хипотетични, иронични, метафорични, наративни заглавия. Обемните аналитични текстове като статиите обикновено са свързани с номинативни, фактологични заглавия, които просто представят темата на анализа и изпълняват единствено информационна функция. Заглавията на интерпретативните текстове са съставени така, че веднага да привлекат читателското внимание. Чрез тях много често потребителят може да направи предположение какво е авторовото отношение към разглежданата тема - това се наблюдава особено ясно при заглавията на личните мнения и коментарите. Чрез 
заглавията се изразява подкрепа към движенията или одобрение на действията на техните активисти. Заглавията обаче служат и за критики към инициативите и желание те да се променят, да не остават в сегашния си вид. Призиви за промяна на социалните роли се намират не само в самите публикации, а и в техните заглавия. Материалите на рубричните автори се характеризират с най-голямо разнообразие и „яркост". Въпреки всичко казано до тук дори сред интерпретативните текстове не се срещат „сензационни" заглавия. Те не са позволени нито на журналистите от The Guardian, нито на гостуващите автори. Представено е личното отношение на пишещия, но то никога не нарушава добрия тон. Често самите заглавия чрез своята формулировка дава повод за размисъл на читателя.

Като примери за заглавия на интерпретативни материали могат да бъдат посочени:

- Sisters, this is our moment to say Time's Up// Сестри, сега е нашето време да кажем Time's Up;

- Three Billboards triumphs as Time's Up dominates the 2018 Bafta// Три билборда триумфира, докато Time's Up доминира на наградите Бафта през 2018 г.;

- A show of power, not fashion: dressing for post-Weinstein Golden Globes// Едно шоу на власт, а не на мода: облеклото за Златните глобуси след Уайнстийн;

- Don't let corporations co-opt \#MeToo// Не позволявайте на корпорациите да превземат \#МеТоо;

- \#MeToo founder Tarana Burke: 'You have to use your privilege to serve other people'// Основателката на \#МеТоо Тарана Бърк: „Трябва да използваш привилегиите си, за да служиш на другите";

- \#MeToo is messy and emotional - but it could change everything// \#МеТоо е объркан и емоционален - но може да промени всичко;

- Checking up on Harvey Weinstein's 'rehab' - how long until he's cured? // Проверяваме „рехабилитацията" на Харви Уайнстийн - колко време остава, докато се излекува?;

- When feminist advance, why do prominent women hold us back// Когато феминистките напредват, защо известните жени ни дърпат назад;

- Frances McDormand is right - forget diversity 'initiatives' - change the system// Франсиз МакДорманд е права - забравете „инициативите" за разнообразие променете системата; 
- How men can show solidarity with the \#MeToo movement// Как мъжете могат да покажат солидарност с движението \#МеTоо;

- If \#MeToo is to work we must call out the men we love// Ако искаме \#МеТоо да проработи, трябва да посочим мъжете, което обичаме;

- A man lost his job to a rape joke. Are you cheering?// Един мъж загуби работата си заради виц за изнасилване. Радвате ли се?

Рубриките и подрубриките, в които най-често се срещат публикации относно движенията "Me Тоо" и "Time's Up" ca: News (Новини), World (Светът), Opinion (Мнения), Culture (Култура), Film (Филми), Books (Книги), Music (Музика) и Lifestyle (Лайфстайл).

Отделните жанрове оказват влияние и върху видовете интонация и аргументация, които са използвани в интерпретативните текстове. В жанрове като статия, коментар и анализ аргументацията е изцяло рационална и фактологична. Интонацията най-често е констатираща, спокойна, неутрална. При тези публикации няма място за емоции и лични пристрастия. На предно място са изведени фактите и безкомпромисният им прочит. Използвани за различни методи за анализ като вторичен анализ на проучвания на други медии или научни организации, собствени анкети, контент анализ.

При личното мнение и рецензията са изведени личните възгледи и пристрастия на всеки автор. Често превес взимат емоциите, оказвайки влияние върху избраната аргументация. Интонацията е призивна, подбуждаща читателите да се замислят над написаното, а нерядко са подканвани да предприемат и действия. Използвана е също отричаща и иронизираща интонация.

\section{The Guardian и движенията "Ме Tоо" и "Time's Up"}

Следващият елемент от контент анализа е свързан с отношението, което е изразено в интерпретативните текстове в The Guardian към движенията "Mе Тоо" и "Time's Up". Данните по този показател могат да бъдат открити в Таблица 2.

\section{Таблица 2}

The Guardian - Изразено отношение към "Ме Tоо" и "Тime's Up" в интерпретативните текстове

\begin{tabular}{|c|c|c|c|c|c|c|}
\hline $\begin{array}{c}\text { Общ брой } \\
\text { текстове }\end{array}$ & \multicolumn{2}{|c|}{$\begin{array}{c}\text { Положително } \\
\text { отношение }\end{array}$} & \multicolumn{2}{c|}{$\begin{array}{c}\text { Негативно } \\
\text { отношение }\end{array}$} & \multicolumn{2}{|c|}{$\begin{array}{c}\text { Не е изразено } \\
\text { отношение }\end{array}$} \\
\hline & Бройки & $\%$ & Бройки & \% & Бройки & $\%$ \\
\hline 212 & 151 & 71,23 & 16 & 7,55 & 45 & 21,23 \\
\hline
\end{tabular}


На първо място с най-голям брой текстове застават материалите, изразяващи положително отношение към движенията. Те са 151 текста или 71,23\% от общия брой интерпретативни публикации. Те са значително повече както от текстовете с негативно отношение към кампаниите, така и тези, при които няма изразена нагласа. При това положителните материали надвишават цели 10 пъти тези с изразена негативна нагласа - 151 броя (71,23\%) срещу само 16 броя (7,55\%). Положителните текстове са и три пьти повече от публикациите без отношение по темата, които са 45 броя (21,23\%).

Веднага може да се направи заключението, че The Guardian има ясно изразено позитивно отношение към "Me Тоо" и "Time's Up". Една от причините за тази нагласа е, че сред авторите, пишещи в онлайн изданието, има множество застьпници на идеите на феминизма. The Guardian дори поддържа специална рубрика на изследователи и идеолози на феминизма, като тези рубрики съществуват много преди началото на настоящото обсъждане на положението на жената в обществото. Такава рубрика е например "This week in patriarchy" - „Тази седмица в патриархата" - която се отличава с висока популярност сред читателите. Друга причина е фактьт, че коментаторите често са на мнение, че движенията показват една отдавнашна нужда на обществото да започне свободното обсъждане на сексуалното насилие и неравенството между половете в различните социални сфери. Авторите одобряват началото на тази дискусия - макар голяма част от тях да отбелязват и недостатъците на "Me Toо" и "Time's Up". Изразеното положително отношение е свързано по-скоро с различните опити за промяна на дискриминационните практики, основаващи се на пола, у дома и на работното място. То е свързано с надеждата, че инициативите ще доведат до трайно обсъждане на проблема сексуално насилие и ще окуражат жертвите на такива посегателства свободно да говорят за преживяванията си.

Следват примери за текстове, изразяващи положителна нагласа към "Ме Тоо" и "Time's Up". За да се спести място, ще бъдат представени само отделни параграфи или части от параграфи на избраните публикации.

\section{Ние създадохме движението \#МеТоо. Сега е време за \#НегТоо}

\section{Тарана Бърк и Алиса Милано, 21 декември 20172.}

2017 г. ще бъде запомнена като годината на \#МеТоо, един повратен момент, в който жените излязоха заедно, за да се подкрепят една друга, нарушавайки мълчанието относно сексуалния тормоз и насилие. Когато научихме, че списание Тайм е избрало „Нарушителите на мълчанието” за Личност на годината, ние бяхме горди с това, че сме помогнали за разпространението на едно послание, 
което е толкова просто колкото и дълбоко: вие не сте сами. Сексуалното насилие не е нищо ново, но дори броят на смелите жени, които се осмелиха публично да споделим нашите най-болезнени преживявания на насилие и тормоз, представлява една вълна, като нови гласове излизат напред всеки ден. Това е една истинска разплата.

При това разплатата няма да бъде единствено и само за американците. Насилието срещу жени и момичета е глобална пандемия. Нито пък този исторически момент може да принадлежи само на Нарушителите на мълчанието, които са имали възможността да проговорят. Ние всички трябва да говорим от името на тези, които не могат да го направят - заради всички тези момичета и жени, които страдат в тишина. Като тази почти скрита жена на корицата на Тайм, описана като „, анонимна болнична служителка от Тексас, която се страхува да разкрие самоличността си".

\section{Фурорът с Азис Ансари не е краят на \#МеТоо. Той е само началото}

\section{Сара Солемани, 22 януари 2018 z.}

Така че пътуването на новия мъж е наистина започнало, при това с малко раздрусване - макар че, да бъдем честни, то дълго време се бавеше. Мъжът ще трябва да продължи да гледа отвъд вербалните и невербалните знащи на неговите интимни партньори, сглобявайки един нов начин на сексуално поведение от съобщенията, които получава в културните прослойки: новините, комедията, музиката, разговорите, неговите сестри, неговите приятели, неговите колеги.

Това не непременно означава край на секса. Жените влизат в сексуални взаимоотношения с невероятен куп от тихи притеснения: насилие и изнасилване от едната страна на спектъра; посрамване, бременност, омаломощаващ, пристъп на ичистит от друга страна. Ако продължим да изживяваме сексуалния живот редом до нашите лични страхове, мъжът може да въплъти отчитането на истинското удоволствие в неговия репертоар. Можете да кажете, че съм мечтателка, но аз наистина вярвам в него.

Нека поне да си позволим да си представим живота в една нова реалност, скитайки се из места, които мъжете свободно обитават - може би някоя странна кръчма или Индия, или което и да място нощем. Представи си да 
отидеш сама до нощен клуб просто защьто ти харесва музиката. Представи си наистина добрият оргазъм да е нормата. Представи си, че свястното момче, което познаваи, е правилото, а не изключението. Представи си, че движението, от което си част, промени всичко. Представи си. Представи си, предизвиквам me.

Материалите с негативно отношение към двете инициативи са свързани с проблемните аспекти в настоящия вид на кампаниите и изразяването на критики към тях. Авторите на подобни публикации често са на мнение, че "Me Toо" и "Time's Up" ще останат просто поредният тренд в социалните медии, който няма да излезе извън границите на онлайн пространството. Според тях кампаниите трябва да бъдат подложени на сериозни промени, за да имат някакъв реален ефект. Някои от авторите обвиняват инициативите в расизъм, тъй като в голяма степен активистите пренебрегват историите на цветнокожите мъже и жени, избирайки да се фокусират върху преживяванията на богатите бели жени от развлекателната индустрия. Привържениците на движенията са обвинявани в „мъжемразство" и желание за отмъщение - критикувани са лицата, които смятат, че всички представители на мъжкия пол са „врагът", считайки ги за потенциални насилници. По този начин активистите могат да изгубят доверието на онези мъже, които до този момент са се застьпвали за правата на жените.

Въпреки това в някои от тези критични към движенията публикации се срещат и възгледи, признаващи значението на "Me Toо" и "Time's Up" и на започналия диалог за премахване на сексуалното насилие. Проблемът всъщност са начините на действие на активистите и нуждата от промяна в механизмите, по които движенията се опитват да постигнат заложените си цели.

Примери за публикации с негативно отношение са:

Какво се случва, когато една от жертвите, използвали \#МеТоо, Азия Ардженто, е сред обвиняемите?

Лаура Кипнис, 24 август 2018 2.

Да, \#МеТоо беше необходимо и закъсняло. Но както при разследванията в кампусите, част от обвиненията е прекалено раздухана. Знаейки всички тези нещуа, ми е невъзможно да вярвам, че всеки обвинител няма друг мотив освен истината и справедливостта, нито пък бих могла да взема самите обвинения като твърди факти.

... 


\section{Дильн Джсонс: „Бях бит и заключван под стьлбището от баща ми" Дильн Дюсоунс, 11 август 2018 г.}

$$
\cdots
$$

Откакто се появиха движенията \#МеТоо и Tiте's Uр жените откриха начин да изразяват себе си и да защџтават равенството във всички аспекти на живота. Но това къде остави мъжете по света? Мъжете с десни убеждения навсякъде по света си мислят: „Наистина ли съм толкова лош?" Ние съжаляваме себе си, но не защото се чувстваме все едно сме направили нещуо лошо, а защуото воден от медиите псевдо съд ни е приел за виновни.

$$
\cdots
$$

Един мъж загуби работата си заради виц за изнасилване. Радвате ли се?

Лаура Кипнис, 22 декември 2018 г.

$$
\cdots
$$

Може би е време да спрем да се крием зад мантрата „кажи истината за властта", когато жените имат власт в изобилие - ние можем да провалим кариерата на мъж с един туит! Нека престанем да приписваме иялата агресия в света на мъжете, а да приемем намата собствена агресия вместо да я замаскираме зад завеса от травма или сексуална етика. Ако ще уволнявате колега заради изтрит пост в социалните медии или ще наказвате дългогодишен колега заради случайно прегрешение, то тогава казвам: поемете отговорност. Ако си отмъщавате за хилядолетия на мъжка власт срещу един филмов критик, нека поне бъдем честни относно начинанието си.

Петият показател на контент анализа се отнася до това дали в текстовете се говори за "Me Too", за "Time's Up", за двете движения или за нито едно от тях.

\section{Таблица 3}

The Guardian - Дали се говори за "Ме Тоо" или за "Time's Up"

\begin{tabular}{|c|c|c|c|c|c|c|c|c|}
\hline $\begin{array}{c}\text { Общ } \\
\text { брой } \\
\text { текстове }\end{array}$ & \multicolumn{2}{|c|}{ "Ме Тоо" } & \multicolumn{2}{|c|}{ "Time's Up" } & \multicolumn{2}{c|}{ Нито едното } & \multicolumn{2}{c|}{ И двете } \\
\hline & Бройки & $\%$ & Бройки & $\%$ & Бройки & $\%$ & Бройки & \% \\
\hline 212 & 157 & 74,06 & 4 & 1,68 & 14 & 6,6 & 45 & 21,23 \\
\hline
\end{tabular}

При интерпретативните текстове се наблюдава съществено разминаване между текстовете, в които се говори за "Ме Тоо", и материалите, в които се говори за инициативата "Time's Up". От тях 157 материала (74,06\% от общото количество интерпретативни текстове) споменават "Ме Тоо", а едва 4 броя (1,68\%) говорят за "Тime's 
Up" (става въпрос за самостоятелното им споменаване) - тази разлика от почти 40 пъти или 153 текста повече е наистина забележителна.

Причината за тази разлика не се крие само във факта, че \#МеТоо съществува три месеца повече от "Time's Up". "Ме Тоо" определено остава по-популярната инициатива в съзнанието на обществото. Известността на тази кампания е тясно свързана с участието на публични фигури от Холивуд в нея, което без всякакво съмнение привлича вниманието на аудиторията. "Time's Up" също се радва на интерес от страна на обществото и медиите, но остава популярно по-скоро сред жертвите на сексуален тормоз на работното място, които могат да се възползват от осигурената от движението финансова и юридическа помощ. Значение има и разпространението на хаштаг \#МеТоо в социалните медии, той е използван от хиляди жени по целия свят, за да споделят своите лични преживявания на сексуално насилие. Дори може да се каже, че "Ме Тоо" или \#МеТоо остава като нарицателно наименование за вълната от обвинения в сексуален тормоз срещу известни личности, но и за желанието на различни хора от множество държави да променят обществените нагласи към този проблем. Оказва се, че "Time's Up" отново остава в сянката на "Me Тоо", като The Guardian също показва тенденция "Time's Up" да се споменава заедно с "Ме Тоо" (като неразделна част от него) по-често отколкото като самостоятелна инициатива, която вече е помогнала на редица жертви на насилие.

\section{Призиви за промяна на социалните роли}

Последният компонент от контент анализа на theguardian.com е свързан със присъствието на призиви за промяна на социалните роли в интерпретативните текстове. Събраните данни по този показател са изведени в Таблица 4.

\section{Таблица 4}

The Guardian - Има ли призив за промяна на социалните роли в интерпретативните текстове

\begin{tabular}{|c|c|c|c|c|}
\hline $\begin{array}{c}\text { Общ брой } \\
\text { текстове }\end{array}$ & \multicolumn{2}{|c|}{ Да Не } \\
\hline & Бройки & \% & Бройки & \% \\
\hline 212 & 120 & 56,6 & 92 & 43,4 \\
\hline
\end{tabular}

По тези данни може да се направи заключението, че в повече от половината интерпретативни текстове се съдържат такива призиви - това са 120 публикации, представляващи 56,6\% от общия брой интерпретативни материали. Текстовете, които не съдържат призив за промяна на социалните роли, са 92 броя $(43,4 \%)$. 
Високият процент на публикации с подобни призиви може да бъде обяснен от една страна с наличието на жанрове, позволяващи изразяването на личното мнение на авторите им, а не просто коментирането и анализирането на факти и събития. Много от тези автори изразяват възгледи, че има належаща нужда от промяна в настоящите взаимоотношения между мъжете и жените. Освен в личните мнения тези призиви са изразявани също и в интервюта и портрети, а дори и в някои коментари.

Срещат се и призиви за промяна в различни аспекти на социалните роли. Обърнато е внимание върху начините за прекратяване на насилието между половете акцент е поставен дори върху необходимостта от прекратяване на сексуалния тормоз между съученици от прогимназиален и гимназиален етап. Изразено е желанието да се промени положението на жената - в частните аспекти на дома и в публичното пространство на работното място, отбелязвайки, че представителите на този пол често са подложени на дискриминация.

Най-големият дял от призивите за промяна на социалните роли обаче се отнасят до отношението на обществото към жертвите на насилие. Авторите отбелязват ниското доверие към техните разкази - особено щом става въпрос за жените, преживели сексуално насилие. Техните истории в повечето случаи са поставени под съмнение, като хората често търсят скрити мотиви за тяхното споделяне - получаване на материална или някаква друга изгода или отмъщение. Тези нагласи на обществото са основна причина защо жертвите на насилие изключително рядко говорят за преживяното. Това е един аспект от съвременното общество, който трябва да бъде изцяло променен, за да се сложи край на насилието -мнение, често изразявано от пишещите за The Guardian.

Има и призиви за назначаването на повече жени на работа на ключови позиции в развлекателната индустрия и в политиката. Това са сфери, които до този момент са считани за непреодолими бастиони на мъжката сила и власт. Смята се, че осъществяването на промени в тях ще доведе до промени в останалите аспекти на живота.

Големият брой интерпретативни текстове, съдържащи призиви за промяна в социалните роли на мъжете и жените, може да бъде обяснен и със значителното количество публикации, изразяващи положително отношение към "Ме Тоо" и "Time's Up". Позитивните нагласи към движенията неминуемо са свързани с предприетите дейности за постигане на равенство между половете, за прекратяване на дискриминацията въ3 основа на пола и за прекратяването на поведението на тормоз и 
насилие. И двете инициативи са свързани именно с желанието за промяна на настоящите взаимоотношения между мъже и жени.

Анализът на онлайн изданието на The Guardian ще завърши с примери, изведени от текстове, съдържащи призиви за промяна на социалните роли.

\section{\#МеТоо не е достатъчен. Сега энените трябва да станат сериозни}

Барбара Кингсловър, 16 януари 2018 г.

$\cdots$

Нека да бъдем наясно: нито една жена не е поискала да живее в една култура на изнасилване. Ние искаме всичко това да приключи и това да е станало още вчера. Смесените сигнали относно женската независимост няма да помогнат за премахването на тази култура, нито пък ще го направи учтивото молене. Женските инстинкти за милост и извинение нямат място в тази игра. Наистина не е възможно да се преиграе относно неизброими, последователни дни на унижение от страна на мъжете, които казват, че нашите преживявания не са истински или че на нас всъщност това ни харесва, или че изглеждаме сладки, когато сме гневни. Гневът трябва да отиде някъде - ако не навън, то навътре, в една психическа термодинамика, която може да превърне нация от жени в тенджера под налягане. Наблюдаването на назначението на началник-хищник изглежда повдигна капака на тенджерата. Ние открихме своя глас, а сега е чудесно време да го използваме и то с тон, който няма да бъде сбъркан с флиртуване.

Не ми казвай това. Не ми прави това. Мразя го.

\#МеТоо в училище: твърде много деца са тормозени сексуално от съученици Нанси Дюко Сейлс, 11 февруари 2018 г.

Казах на момичето, което видях, че е тормозено сексуално пред училището на моята улица, нещчата, които ми се искаше някой да бе казал на мен преди повече от 40 години: „На никого не му е позволено да ти прави това. Всеки, който го прави, греши - те извършват престьпление. Искаше ми се да ми позволиш да кажа на някого - ами ако не им кажа името ти, а просто кажа имената на тези момчета... добре ли си?"

Тя толкова ми напомни за мен самата на тази възраст, когато просто си отметна косата и каза: „Да, не е голям проблем. Добре съм." И тя си тръгна. Следващия път, когато чуете някого да поставя под въпрос това дали трябва да учим децата 
относно съгласието, или да казват, че \#МеТоо е „отишло твърде далеч", моля, спомнете си за нея.

Отиде ли \#МеТоо твърде далеч или не достатъчно далеч? Отговорът е и двете Лаура Кипнис, 13 януари 2018 г.

Политическото изискване за момента след \#МеТоо е настояването, че контролът върху телата ни е началото на свободата. Не нейният край, а началната ѝ точка. Свободата трябва да бъде по-понятийна, тя същьо така трябва да бъде въплътена.

\section{Заключение}

В края на статията могат да бъдат направени следните изводи:

- На уебсайта theguardian.com има много повече текстове, в които се говори за "Ме Тоо", в сравнение с публикациите, отнасящи се до "Time's Up". Оказва се, че \#МеТоо се споменава в пъти повече отколкото другата кампания. Движението "Ме Тоо" съществува три месеца повече от другата инициатива, но това не единствената причина за разминаването в броя текстове за двете кампании. Популярността на "Ме Тоо" е тясно свързана с обвиненията срещу филмовия продуцент Харви Уайнстийн и с последвалата „вълна" на споделяне на истории за преживян сексуален тормоз или сексуално насилие. Може дори да се каже, че "Ме Тоо" остава като нарицателно име за масовото споделяне на преживявания на сексуално посегателство. В тях основно място заемат разказите на знаменитости, които неминуемо привличат общественото внимание. Историите за известни личности привличат много повече интереса на хората отколкото тези за никому неизвестни лица.

- Отразяването на "Ме Тоо" и "Time's Up" става чрез разнообразни интерпретативни жанрове, позволяващи представянето на различни страни на социалните факти. Сред тези жанрове особено място заемат личните мнения на рубрични автори, на журналисти от медията и на гостуващи автори. На читателя е дадена възможност да се запознае с напълно различни гледни точки към фактите, а чрез това и да формира своя собствен възглед за случващото се.

- Интерпретативните текстове на theguardian.com изразяват основно положително отношение към двете инициативи. Фактьт, че публикациите с положителна нагласа надвишават 10 пъти повече материалите с негативно отношение, е ясна индикация за нагласата на това онлайн издание към "Me Тоo" и "Time's Up". То изразява подкрепа към действията на активистите на тези движения, като се осъзнава необходимостта от съществуването на инициативите. Нуждата от обществено обсъждане на проблема 
сексуално насилие е значителна, тази публична дискусия вече е закъсняла. Без съмнение фактор за тази позитивна нагласа на медията към "Me Тоо" и "Time's Up" е свързана с многото застьпници на феминизма, пишещи за The Guardian. Дълго преди появата на хаштаг \#МеТоо тези журналисти са поддържали специални рубрики относно идеите на феминизма и промотирането на правата на жените и преодоляването на дискриминацията въз основа на пола. В публикациите не са подминати и проблемните страни на движенията и недостатъчността на предприетите до този момент действия, но авторите предпочитат да се съсредоточат върху значимостта им за премахването на табуто относно публичното обсъждане на сексуалния тормоз, което съществува до този момент.

- В изследвания масив от текстове отразяването на движенията "Ме Тоо" и "Time's Up" е свързано с изразяването на призиви за промяна на социалните роли на двата пола в обществото. Мнозинството от авторите са на мнение, че инициативите дават една добра възможност за преодоляване на дискриминацията въз основа на пола във всички социални сфери. Срещат се призиви за назначаването на повече жени на високопоставени постове и за промяна в „хищническото" поведение на някои мъже към представителките на другия пол. Най-много обаче са изразените призиви хората да се доверят на разказите на жертвите на сексуално насилие. До този момент техните думи са посрещани с подозрението, че са неверни и че жертвите просто търсят внимание и съчувствие или искат да си отмъстят. Промяната в нагласите на обществото към жертвите ще позволи потърпевшите да говорят по-свободно за преживяванията си. Това пък е първата стъпка за премахването на сексуалното насилие от ежедневния живот на хората.

\section{Използвана литература}

Bargh, J.A., Raymond, P. The naïve misuse of power: nonconscious sources of sexual harassment. Journal of Social Issues, 51, 85-96. https://doi.org/10.1111/j.1540-4560.1995.tb01310.x

Blakely, K. (2009, September 6). The "new" sexual harassment. The Forbes. https://www.forbes.com/2009/08/06/sexual-harassment-office-forbes-womanleadership-affairs.html .

Brodsky, C. (1976). The harassed worker. P.C. Heath.

Crain, K.A., Heischmidt, K.A. (2003). Implementing business ethics: Sexual harassment. Journal of Business Ethics, 14(4), 299-308. https://www.jstor.org/stable/25072648

DOI: $10.1177 / 0018726713493028$ 
Frankel Paul, E. (1990). Sexual harassment as sex discrimination: A deflective paradigm. Yale Law \& Policy Review, 8(2), 333-365. https://digitalcommons.law.yale.edu/cgi/viewcontent.cgi?article=1189\&context=ylpr

George, K. (2018). \#MeToo and Human Rights Language in the Social Media Era. Right Now. http://rightnow.org.au/opinion-3/metoo-human-rights-language-social-media-era/ .

Kalof, L. et al. (2001). The influence of race and gender on student Self-reports of sexual harassment by college professors. Gender \& Society, 15, 282-302. DOI???? https://www.jstor.org/stable/3081848

Leung, R., Williams, R. (2019). \#MeToo and intersectionality: An examination of the \#MeToo movement through the R. Kelly scandal. Journal of Communication Inquiry, 43(1), 349371. https://doi.org/10.1177/0196859919874138

MacKinnon, C. A. (1979). Sexual harassment of working women: A case of sex discrimination. Yale University Press.

MacKinnon, C.A. (2002). The logic of experience: reflection on the development of sexual harassment law. Georgetown Law Journal, 9, 813-833. OI???? https://heinonline.org/HOL/LandingPage?handle=hein.journals/glj90\&div=38\&id=\&p age $=$

Macnamara, J. (2005). Media content analysis: Its uses, benefits and best practice methodology. Asia Pacific Public Relations Journal, 6(1), 1- 34.

Mainiero, L.A., Jones, K.J. (2013). Sexual harassment versus workplace romance: Social Media spillover and textual harassment in the workplace. Academy of Management Persepctives, 27(3), 187-203. https://doi.org/10.5465/amp.2012.0031

Monova, T. (1999). Mediatekstat [The Mediatext]. Paradoks.

Monova, T. (2000). Dumite, koito razdelyat. Politicheskiyat diskurs v pechata [Words which divide. Political discourse in print media]. Paradoks.

Monova, T. (2012). Noviyat zhurnalizam na prehoda. Mezhdu korporativnia kartser i novite medii [The New Journalism of the Transition Period. Between corporate solitary confinement and new media]. Paradoks.

Newman, M.A. (1999). Sexual harassment and productivity: It's not just a U.S. problem. Public Productivity and Management Review, 19(2), 172-186. https://doi.org/10.2307/3380496

Patai, D. (1988). Heterophobia: Sexual harassment and the future of feminism. Rawman \& Littlefield. 
Schultz, V. (2001). Talking about harassment. Journal of Law and Policy, 9, 417-433. http://dx.doi.org/10.2139/ssrn.289239

Tangri, S.S., Burt, M.R., \& Johnson, L.B. (1982). Sexual harassment at work: Three explanatory models. Journal of Social Issues, 38, 33-54. https://doi.org/10.1111/j.15404560.1982.tb01909.x

Tavris, C., Offir, C. (1977). The longest war. Harcourt, Brace, Jovanovich.

Thacker, R.A. (1996). A descriptive study of situational and individual influences upon individuals' responses to sexual harassment. Human Relations, 49, 1105-1122. https://doi.org/10.1177/001872679604900805

Thomson, K. (2018, June 12). Social media activism and the \#MeToo movement. Medium. https://medium.com/@kmthomson.11/social-media-activism-and-the-metoomovement-166f $452 \mathrm{~d} 7 \mathrm{fd} 2$.

Zilles, C. (2017, May 3). The \#MeToo movement shows the power of social media. Social Media HQ. https://socialmediahq.com/the-metoo-movement-shows-the-power-of-socialmedia/ . 